\title{
Global Transcriptome Profiling Identified Transcription Factors, Biological Process, and Associated Pathways for Pre-Harvest Aflatoxin Contamination in Groundnut
}

\author{
Pooja Soni ${ }^{1,2}$, Arun K. Pandey ${ }^{3}$, Spurthi N. Nayak ${ }^{4}{ }^{\mathbb{D}}$, Manish K. Pandey ${ }^{1} \mathbb{D}$, Priya Tolani ${ }^{1}$, Sarita Pandey ${ }^{1}$, \\ Hari K. Sudini ${ }^{5}$, Prasad Bajaj ${ }^{1}$, Jake C. Fountain ${ }^{6}$, Prashant Singam ${ }^{2}$, Baozhu Guo ${ }^{7}$ (D) \\ and Rajeev K. Varshney $1,8, *$ (D)
}

Citation: Soni, P.; Pandey, A.K.; Nayak, S.N.; Pandey, M.K.; Tolani, P.; Pandey, S.; Sudini, H.K.; Bajaj, P.; Fountain, J.C.; Singam, P.; et al. Global Transcriptome Profiling Identified Transcription Factors, Biological Process, and Associated Pathways for Pre-Harvest Aflatoxin Contamination in Groundnut. J. Fungi 2021, 7, 413. https:// doi.org/10.3390/jof7060413

Academic Editor: Joseph M. Bliss

Received: 1 May 2021

Accepted: 23 May 2021

Published: 26 May 2021

Publisher's Note: MDPI stays neutral with regard to jurisdictional claims in published maps and institutional affiliations.

Copyright: (c) 2021 by the authors. Licensee MDPI, Basel, Switzerland. This article is an open access article distributed under the terms and conditions of the Creative Commons Attribution (CC BY) license (https:/ / creativecommons.org/licenses/by/ $4.0 /)$.
1 Center of Excellence in Genomics \& Systems Biology (CEGSB), International Crops Research Institute for the Semi-Arid Tropics (ICRISAT), Hyderabad 502324, India; poojasoni.sps@gmail.com (P.S.); m.pandey@cgiar.org (M.K.P.); priyatolani90@gmail.com (P.T.); isarita06@gmail.com (S.P.); p.bajaj@cgiar.org (P.B.)

2 Department of Genetics, Osmania University, Hyderabad 500007, India; prashantsingam@gmail.com 3 College of Life Science, China Jiliang University (CJLU), Hangzhou 310018, China; pandeyarun@cjlu.edu.cn 4 Department of Biotechnology, University of Agricultural Sciences, Dharwad 580005, India; nayaksn@uasd.in

5 Theme-Integrated Crop Improvement, Research Program-Asia, International Crops Research Institute for the Semi-Arid Tropics (ICRISAT), Hyderabad 502324, India; h.sudini@cgiar.org

6 Department of Biochemistry, Molecular Biology, Entomology, and Plant Pathology, Mississippi State University, Starkville, MS 39762, USA; jcf416@msstate.edu

7 Crop Genetics and Breeding Research Unit, USDA-ARS, Tifton, GA 31793, USA; baozhu.guo@usda.gov

8 State Agricultural Biotechnology Centre, Centre for Crop and Food Innovation, Food Futures Institute, Murdoch University, Murdoch, WA 6150, Australia

* Correspondence: r.k.varshney@cgiar.org or rajeev.varshney@murdoch.edu.au

\begin{abstract}
Pre-harvest aflatoxin contamination (PAC) in groundnut is a serious quality concern globally, and drought stress before harvest further exacerbate its intensity, leading to the deterioration of produce quality. Understanding the host-pathogen interaction and identifying the candidate genes responsible for resistance to PAC will provide insights into the defense mechanism of the groundnut. In this context, about 971.63 million reads have been generated from 16 RNA samples under controlled and Aspergillus flavus infected conditions, from one susceptible and seven resistant genotypes. The RNA-seq analysis identified 45,336 genome-wide transcripts under control and infected conditions. This study identified 57 transcription factor (TF) families with major contributions from 6570 genes coding for bHLH (719), MYB-related (479), NAC (437), FAR1 family protein (320), and a few other families. In the host (groundnut), defense-related genes such as senescenceassociated proteins, resveratrol synthase, seed linoleate, pathogenesis-related proteins, peroxidases, glutathione-S-transferases, chalcone synthase, ABA-responsive gene, and chitinases were found to be differentially expressed among resistant genotypes as compared to susceptible genotypes. This study also indicated the vital role of ABA-responsive $A B R 17$, which co-regulates the genes of $\mathrm{ABA}$ responsive elements during drought stress, while providing resistance against $A$. flavus infection. It belongs to the PR-10 class and is also present in several plant-pathogen interactions.
\end{abstract}

Keywords: aflatoxin; Aspergillus flavus; biotechnology; food safety; gene expression; genomics; pre-harvest aflatoxin contamination (PAC); RNA-seq; transcriptome analysis

\section{Introduction}

Aflatoxins are strong cancer-causing and teratogenic mycotoxins produced in crops such as groundnut, maize, cottonseed, chilies, and tree nuts upon infection by Aspergillus flavus and A. parasiticus. Groundnut or peanut (Arachis hypogaea L.) is the most susceptible crop to aflatoxin contamination under favorable conditions [1,2]. Aflatoxin exposure can have significant negative impacts on human health. It is also considered as a growth 
development retardant in the young [3] and an immune suppressor [4], contributing to susceptibility to AIDS [5]. In groundnut, Aflatoxin $\mathrm{B}_{1}\left(\mathrm{AFB}_{1}\right)$ produced by the $A$. flavus and $A$. parasiticus is believed to be the essential driver of liver disease, alongside ongoing hepatitis $B$ and $C$ infections [6] and intense aflatoxicosis $[7,8]$. The resistance mechanisms to aflatoxin contamination in groundnut can be delineated into resistance to pre-harvest aflatoxin contamination (PAC), post-harvest aflatoxin contamination, and fungal colonization on seeds $[2,9,10]$. The PAC is a vital segment of aflatoxin which, if ignored, increases in intensity during post-harvest operations such as packing, transportation and storage [11-13]. In this condition, plants look healthy from the outside but the contamination can be seen inside the pods, is possible only after harvest. The inoculum carried in the pre-harvest conditions are the major source of contamination found at post-harvest and storage stages. Abiotic stresses, especially drought and heat, exacerbate pre-harvest aflatoxin production in groundnut $[14,15]$. Pre-harvest aflatoxin contamination may be diminished in groundnut by identifying drought resistant cultivars, adequate water system facilities, and best post-management practices [15-17]. Under drought conditions, the cracking of pod walls may result in increased penetration of $A$. flavus and subsequent aflatoxin contamination in the kernels [18]. The drought conditions also decreased the production of phytoalexin, due to low kernel water activity, which plays an important role in defense mechanisms against aflatoxin contamination [19]. Thus, drought is a factor which plays a key role in exacerbating aflatoxin contamination in groundnut $[20,21]$.

The next-generation sequencing (NGS) based transcriptomic approach examines resistance mechanisms by identifying novel genes and pathways [22]. Few reports are available related to expression profiles for selected tissues of plant development and improvement in groundnut utilizing microarray innovation $[23,24]$ and transcriptome sequencing $[25,26]$. One of the previous transcriptome analysis studies highlighted the key role of fatty acid and abscisic acid (ABA) biosynthesis pathways, in addition to identifying ABR1, a repressor and a susceptibility factor which acts on ABA signaling pathways and promote PAC [21]. However, the unavailability of reference genomes either restricted such studies or could not provide conclusive information during in-vitro investigation of Aspergillus disease with different degrees of aflatoxin contamination in groundnut [27]. Nevertheless, reference genomes have now become available not only for diploid progenitors [28,29] but also for both of the subspecies of cultivated groundnut [30-32]. These genome assemblies are great sources for understanding the structural and functional behavior of complex traits including aflatoxin contamination [33-35]. In view of the above, the current RNA-seq study was conducted for developing a better understanding of the molecular mechanism in groundnut for PAC resistance against $A$. flavus using seven resistant genotypes and one susceptible genotype under infected and control conditions in the glasshouse conditions. This study provides putative candidate genes that were differentially expressed in these cultivars, and metabolic pathways associated with resistance to fungal infection and PAC. The potential candidate genes can be targetted for further validation and for developing marker assays to accelerate breeding for low aflatoxin contamination in groundnut.

\section{Material and Methods}

\subsection{Plant and Fungal Material}

Seven resistant genotypes (ICGV 91284, ICGV 94379, ICGV 91324, ICGV 91278, ICGV 91315, ICGV 93305, and J 11) and one susceptible genotype (JL 24) were used in this transcriptome study for understanding PAC resistance mechanisms. These seven resistant genotypes were safe, within the permissible level $(<15 \mathrm{ppb})$ of aflatoxin four to eight weeks after harvest. Fungal cultures of highly toxigenic strains of $A$. flavus (isolate of 11-4) were used for the inoculation. Characterization of the toxigenic A. flavus strain (AF 11-4) was done at the Groundnut Pathology Unit, ICRISAT. The AF 11-4 strain was maintained and sub-cultured on Potato Dextrose Agar (PDA) plates, and was further used in this present study for field inoculation. A conidial suspension was prepared and adjusted to a concentration of $1 \times 10^{6}$ spores $/ \mathrm{mL}$, after 7 days of incubation at $25^{\circ} \mathrm{C}$. 


\subsection{Experimental Setup}

The seeds of all the eight genotypes were disinfected with $0.1 \%$ mercuric chloride solution for $2-5 \mathrm{~min}$ with gentle shaking and $1 \mathrm{~min}$ in $70 \%$ ethanol followed by rinsing with sterile water three to four times. Care was taken to completely sterilize the soil mixture (red soil + sand (2:1)) in a horizontal autoclave. The sterilized soil mixture was placed in pots of 10" diameter with 5-7 g of diammonium phosphate (DAP) in each pot. Before sowing, the seeds were treated with systemic fungicide SAAF at $1 \mathrm{~g} / \mathrm{kg}$ of seeds. In a glasshouse, 10 plants for each genotype were maintained for control and treatment. Both the control and infected sets were allowed to grow normally for 30 days. The treatment set was inoculated with the $A$. flavus inoculum that was grown on the autoclaved sorghum grains 30 days after sowing (DAS) at the pod zone. The second inoculation was made 45 DAS followed by a third inoculation at 60 DAS. Two irrigations per week were given until 75 DAS, and a dry spell was mimicked from 75 DAS to 90 DAS. The plants were irrigated optimally to prevent soil moisture stress during all of the crop growth stages except for imposing the end-of-season (3-4 weeks before harvest) drought, which favored $A$. flavus penetration and subsequent entry into pods. Water was applied to the pots by hand using a hose. Each time approximately $10 \%$ more water was applied than the pot could hold, ensuring that the applied water percolated into the soil rather than overflowing from the top of the pot. A life-saving irrigation was given 90 DAS and harvesting was carried out at 120 DAS. Further harvested seeds samples were used for toxin estimation and RNA-seq analysis.

\subsection{Aflatoxin Quantification in Control and Infected Samples}

Quantitative estimation was done for total aflatoxins under control and infected conditions following the protocol of Waliyar et al. [36]. An indirect competitive enzymelinked immune sorbent assay (ELISA) approach was used, and polyclonal antibodies were produced against $\mathrm{AFB}_{1}$ ) [36]. To do so, we utilized polyclonal antibodies against $\mathrm{AFB}_{1}$ for the quantitative assessment of all of the aflatoxins. For polyclonal antibody production, aflatoxin $\mathrm{B}_{1}$-bovine serum albumin ( $\mathrm{AFB}_{1}$-BSA) was acquired from Sigma-Aldrich (Catalog No. 6655, Suffolk, NY, USA).

\subsection{RNA Extraction, Illumina Sequencing and Data Pre-Processing}

For RNA isolation, frozen seeds were homogenized into a fine powder using a chilled mortar and pestle. Total RNA was extracted from $5 \mathrm{~g}$ of seeds using the "NucleoSpin ${ }^{\circledR}$ RNA Plant" kit (Macherey-Nagel, Düren, Germany) according to the manufacturer's instructions. A quality check of RNA samples was performed using a Nanodrop 1000 spectrophotometer (Thermo Fisher Scientific Inc, Waltham, MA, USA) and an Aglient RNA 6000 Nano chip on an Agilent 2100 Bioanalyzer (Agilent technologies, Palo Alto, CA, USA). The RNA samples with a $260 / 280$ ratio of 1.8 to 2.1 or a $260 / 230$ ratio of 2.0 to 2.3 , and a RIN (RNA integrity number) value of $>8.0$, were used for cDNA library preparation. A total of 16 libraries (8 genotypes $\times 2$ treatment levels) were sequenced on the NextSeq 500 platform to generate 75-base paired-end reads at Genotypic Technology Pvt. Ltd. (Bengaluru, India). $5 \mu \mathrm{g}$ of the total RNA pooled in an equivalent amount from two replicates were utilized for the development of a cDNA library utilizing an mRNA-Seq test prep unit (Illumina Inc., San Diego, CA, USA). The raw reads were subjected to quality filtering using NGSQCbox [37] and Trimmomatic v0.33 [38] to remove low-quality sequencing reads with ambiguous nucleotides and any adapter contamination. The read quality was assessed using FastQC.

\subsection{Trimming, Alignment and Functional Annotation of Sequences}

Sequencing data were processed post-trimming following approaches mentioned in Clevenger et al. [39] and Chen et al. [29]. Tophat2 v2.1.1 was used for alignment against two diploid progenitor genomes of cultivated groundnut with parameters set to default [40]. The aligned reads were then separated for reads aligned on A. duranensis (A genome) and $A$. ipaensis (B genome) and assembled separately based on the genome-guided approach using 
trinity v2.2.0 [41]. Further, the unaligned reads were also assembled using the de novo approach. The assembled transcripts for each sample were then filtered for redundancy using the evidential gene pipeline [42]. The filtered reads of the 16 resultant samples were mapped onto assembled transcripts and the expression level of transcripts was estimated in terms of fragments per kilobase of transcript per Million (FPKM) using the Cuffdiff program within Cufflinks v2.2.1 [43]. A transcript was considered to be expressed when FPKM $\geq 1$ in at least one sample. For a transcript to be significant, $\mid \log _{2}$ (fold change) $\mid \geq 2$ and $p$-values $\leq 0.05$ were considered. In addition, to visualize differential gene expression patterns between the 8 control and 8 infected genotypes, a Venn diagram was constructed.

\subsection{Transcript Annotations, Pathway Assignment and Annotations of Transcription Factors}

Alignment was performed to identify significant hits for genes exposed to the BLASTX similarity search against NCBI non-redundant (nr) protein database taxon Viridiplantae with a cut-off of E-value $\leq 1 \times 10^{-5}$. BlastX results were then used to distinguish gene ontology (GO) annotation and pathways through Blast2GO v5 [44]. By using a tissue specificity index $(\tau)$ as described by Yanai et al. [45], the sample-specific genes were identified with following the formula:

$$
\tau=\frac{\sum_{i=1}^{N}\left(1-x_{i}\right)}{\mathrm{N}-1}
$$

where $\mathrm{N}$ is the number of samples and $x_{i}$ is the expression value of a gene normalized by most extreme value across all samples. The estimation of $\tau$ goes from 0 to 1 , where the higher the value more plausible the specific expression at that stage. Transcription factors (TFs) are key proteins that control the regulation of the gene expression in various phases of the life cycle. The TFs were annotated in transcriptome sequencing data generated on eight infected and control genotypes using BLASTX with the cut off E-value $\leq 1 \times 10^{-10}$ by comparing plant transcription factors (PlantTFDB) [46].

\section{Results}

\subsection{Transcriptome Sequencing and Gene Expression Analysis}

A total of 971.63 million paired-end reads were produced from 16 samples (Table 1) and 941.93 million paired-end reads ( $96.94 \%$ of the total paired-end reads) were retained for the downstream process after the filtration of low-quality reads. An average of $94.13 \%$ of the filtered reads were mapped to the assembled transcripts. Of the 56,239 transcripts identified among various tissue samples, 45,336 genes (Table S1) had an abundance of FPKM $\geq 1$ in at least one sample. The details of annotation, gene ontology (GO) IDs and names, and the corresponding putative pathways of each of 45,336 transcripts are provided in Table S1. Further, based on expression levels, they were ordered into four significant classes (FPKM $<2,2 \leq$ FPKM $<10,10 \leq$ FPKM $<20$ and FPKM $>20$ ) in sixteen samples. The distribution of genes expressed in 16 samples under these categorizations based on their expression levels (low, moderate, and high) has been shown in Figure 1.

Upon examining the genes with FPKM $\geq 20$, the highest number of highly expressed genes were identified in the moderately resistant genotype J 11 (C) (7925 genes) and susceptible genotype ICGV 93305 (I) (7765 genes). Of the total 56,239 genes identified across genotypes, the highest number $(41,697)$ of genes was expressed in ICGV 93305 (C) followed by 41,892 genes in ICGV 91284 (I) and 41,433 genes in ICGV 91315 (I) (Figure 1). Further, 426 stably expressed genes were identified across tissues and samples based on coefficient of variation (CV). In light of the large diversity of analyzed tissues in this study, the top constitutively expressed genes which displayed a CV between 2.50 to $3.45 \%$ were marked for further investigation into their pre-harvest aflatoxin resistance. These genes belong to ABA-responsive, pathogenesis-related proteins (PR proteins), peroxidases, glutathione-S-transferases, seed linoleate, chalcone synthase, defense-related genes, and chitinases categories. 
Table 1. Summary of the sequence data generated from 16 RNA libraries through Illumina sequencing.

\begin{tabular}{cccc}
\hline Sample Name & $\begin{array}{c}\text { Total Raw Reads } \\
\text { (Millions) }\end{array}$ & $\begin{array}{c}\text { Total QC Reads } \\
\text { (Millions) }(\mathbf{Q}>\mathbf{2 0})\end{array}$ & $\begin{array}{c}\text { Overall Read } \\
\text { Mapping (\%) }\end{array}$ \\
\hline ICGV 91278 (C) & 65.12 & 64.11 & 94.90 \\
ICGV 91284 (C) & 62.03 & 58.89 & 94.80 \\
ICGV 91315 (C) & 65.42 & 63.76 & 94.80 \\
ICGV 91324 (C) & 60.15 & 58.79 & 94.40 \\
ICGV 93305 (C) & 55.24 & 53.00 & 94.20 \\
ICGV 94379 (C) & 82.69 & 80.57 & 94.30 \\
J 11 (C) & 44.60 & 42.62 & 94.80 \\
JL 24 (C) & 57.92 & 56.55 & 94.20 \\
ICGV 91278 (I) & 58.17 & 56.52 & 94.20 \\
ICGV 91284 (I) & 60.47 & 58.71 & 93.90 \\
ICGV 91315 (I) & 76.38 & 73.46 & 94.30 \\
ICGV 91324 (I) & 58.63 & 56.95 & 94.40 \\
ICGV 93305 (I) & 61.50 & 59.63 & 94.40 \\
ICGV 94379 (I) & 55.80 & 54.31 & 94.40 \\
J 11 (I) & 54.94 & 52.38 & 89.90 \\
JL 24 (I) & 52.58 & 51.67 & - \\
Total & 971.63 & 941.93 & 89.90 \\
Minimum & 44.60 & 42.62 & 94.90 \\
Maximum & 82.69 & 80.57 & 94.13 \\
Average & 60.73 & 58.87 & \\
\hline
\end{tabular}

C-Control condition; I-Infected condition; * Susceptible check.

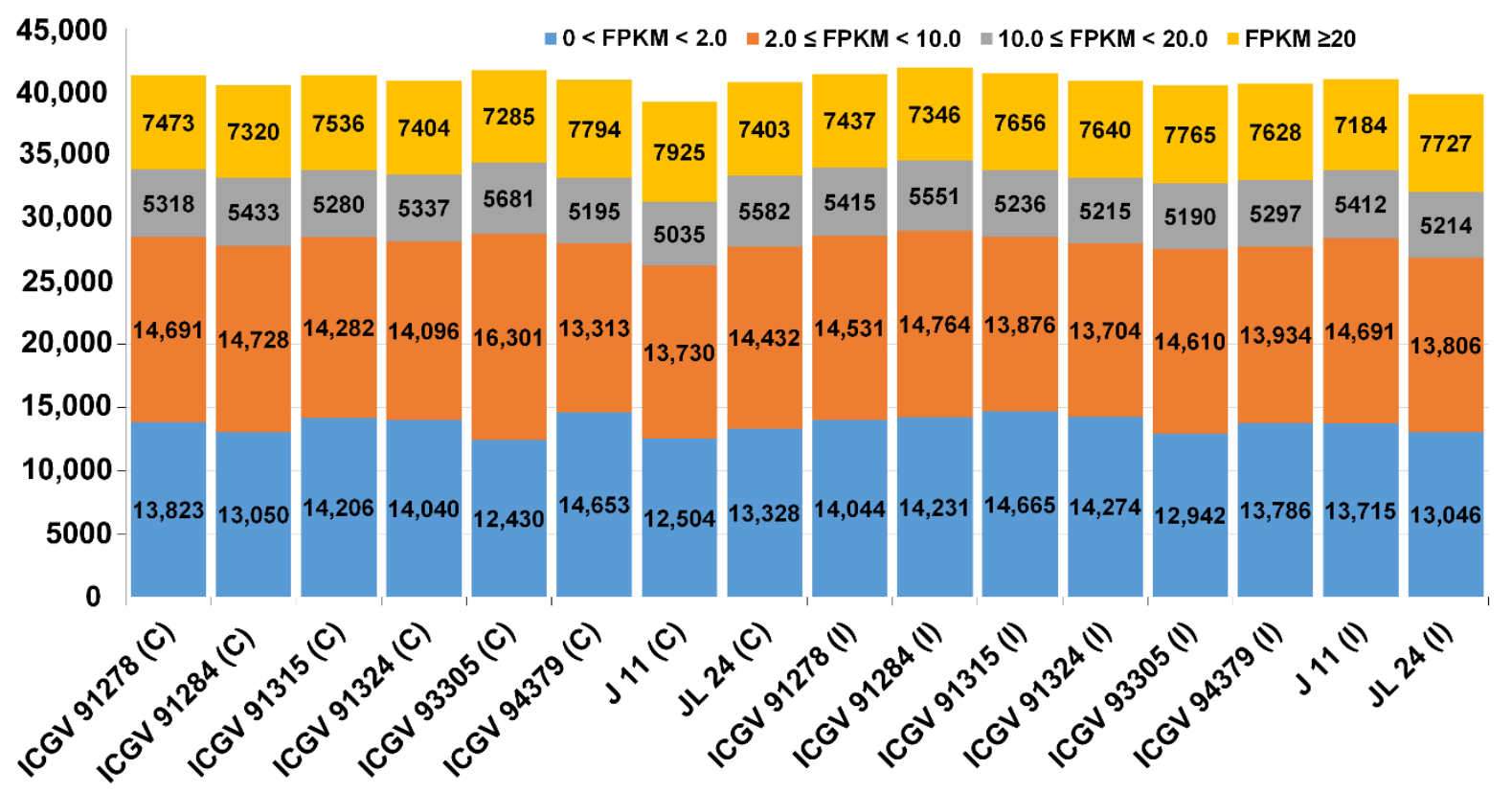

Figure 1. Distribution of genes expressed in 16 samples. Based on expression level, genes were grouped into four classes $($ FPKM $<2,2 \leq$ FPKM $<10,10 \leq$ FPKM $<20$ and FPKM $>20)$ in sixteen samples.

\subsection{Clustering and Principal Component Analysis}

Principal component analysis (PCA) was performed to explore the relationship among the samples based on their expression values (Figure 2). A dendrogram was first constructed using the global expression dataset across the 16 samples with two major clusters, namely Cl-I and Cl-II. The dendrogram represented the clustering of resistant and susceptible genotypes together irrespective of treatment, hence further clustering was done only for eight infected samples to rule out the effect of genotype on treatments. This new clustering grouped six genotypes into three different clusters. To further validate the clustering obtained from a PCA using the expression dataset across the 8 samples, grouping 
was done based on PAC percentage and estimation of aflatoxin production which formed three groups for six resistant genotypes. Groups 1 and 2 consisted of a single genotype each, namely ICGV 91278 and ICGV 91284, respectively, while group 3 consisted of four genotypes, namely ICGV 91315, ICGV 91324, ICGV 93305, and ICGV 94379. J 11 was used as a resistant check and JL 24 was used as a susceptible check (Figure 2). Group 1 genotypes have $\mathrm{PAC} \leq 2 \mu \mathrm{g} / \mathrm{kg}$ and $\mathrm{AP} \leq 10 \mu \mathrm{g} / \mathrm{kg}$, group 2 have $\mathrm{PAC} \leq 2 \mu \mathrm{g} / \mathrm{kg}, \mathrm{AP} \leq 2 \mu \mathrm{g} / \mathrm{kg}$ and group 3 have PAC $\geq 40 \mu \mathrm{g} / \mathrm{kg}, \mathrm{AP} \leq 2 \mu \mathrm{g} / \mathrm{kg}$. J 11 was used as a resistant check $(\mathrm{PAC}<2 \mu \mathrm{g} / \mathrm{kg} ; \mathrm{AP} \leq 0 \mu \mathrm{g} / \mathrm{kg}$ ) and JL 24 was used as susceptible check (PAC > $90 \mu \mathrm{g} / \mathrm{kg}$; $\mathrm{AP}>940 \mu \mathrm{g} / \mathrm{kg})$.

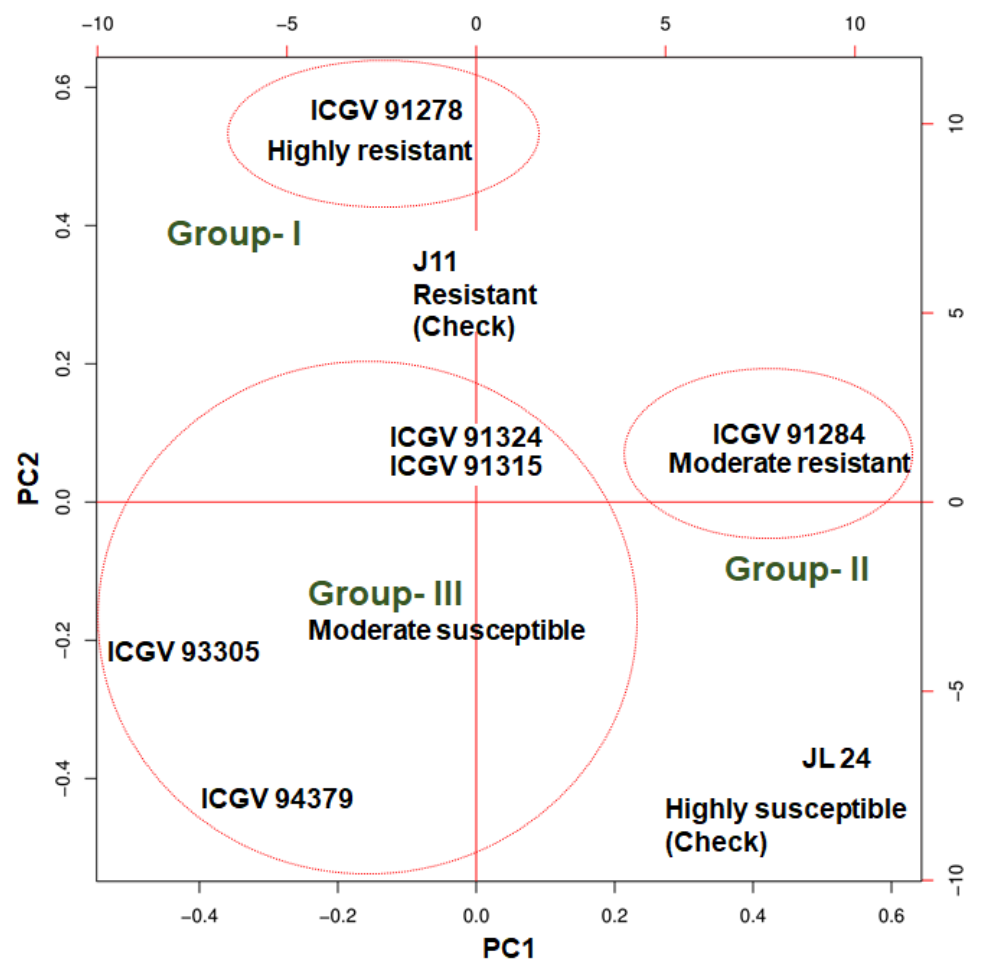

Figure 2. Principal component analysis depicting correlation among samples based on gene expression data. Group 1 (ICGV 91278), highly resistant, group 2 (ICGV 91284) moderately resistant, group 3 (ICGV 91324, ICGV 91315, ICGV 93305, ICGV 94379), moderately susceptible, in comparison to highly susceptible check JL24.

\subsection{Differential Expressed Genes under Control and Infected Conditions}

Group-wise comparisons were made using RNA-seq data between group 1: resistant J 11(I) vs. resistant genotypes (ICGV 91278, ICGV 91315, ICGV 93305, ICGV 91284, ICGV 94379, ICGV 91324) in infected condition, group 2: susceptible JL 24 vs. resistant genotypes (ICGV 91278, ICGV 91315, ICGV 93305, ICGV 91284, ICGV 94379, ICGV 91324) in infected condition, group 3: resistant J 11(C) vs. resistant genotypes (ICGV 91278, ICGV 91315, ICGV 93305, ICGV 91284, ICGV 94379, ICGV 91324) under control conditions, and group 4: susceptible JL 24 vs. resistant genotypes (ICGV 91278, ICGV 91315, ICGV 93305, ICGV 91284, ICGV 94379, ICGV 91324) under control conditions.

A total of 541, 695, 921, and 780 differentially expressed transcripts were detected in group 1, group 2, group 3 and group 4, respectively (Figure 3A-C). Comparing these transcripts across the groups, 149 differentially expressed transcripts were specific to Group 1. Likewise, 259, 378 and 256 differentially expressed transcripts were detected specific to group 2, group 3 and group 4 respectively. Further, 117 unique differentially expressed transcripts were found common across the four groups (Figure 3C). Additionally, 840 and 729 differentially expressed transcripts were identified upon comparing 7 resistant genotypes with the susceptible check (JL 24) under control conditions (group 5) and 
in infected condition (group 6), respectively (Figure 3D). Biological processes such as metabolic and cellular processes, single-organism processes, biological regulation, and localization were identified based on the GO annotation of these expressed transcripts. A volcano plot depicted significant up- and down-regulation of DEGs between ICGV 91278 (I) vs. JL 24 (I) (total 292; up 115; down 177) and ICGV 91284 (I) vs. JL 24 (I) (total 156; up 103 down 53) samples (Figure 4). Altogether 448 DEGs including 218 significantly upregulated and 230 down-regulated with $\log _{2}$ fold change values $\geq 2$ or $\leq-2$, respectively, were identified (Figure 4) between susceptible check vs. infected genotypes.

A

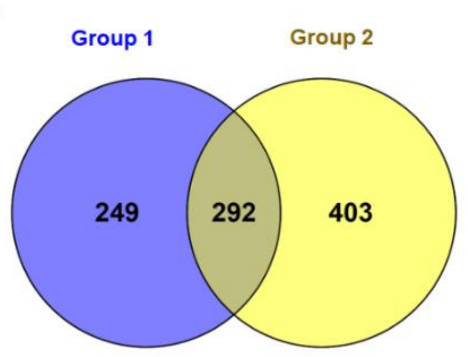

C

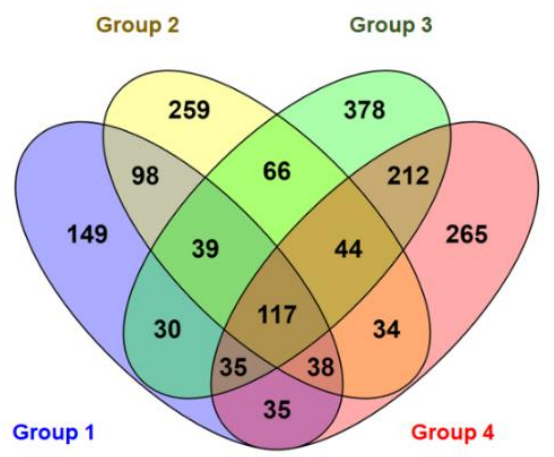

B
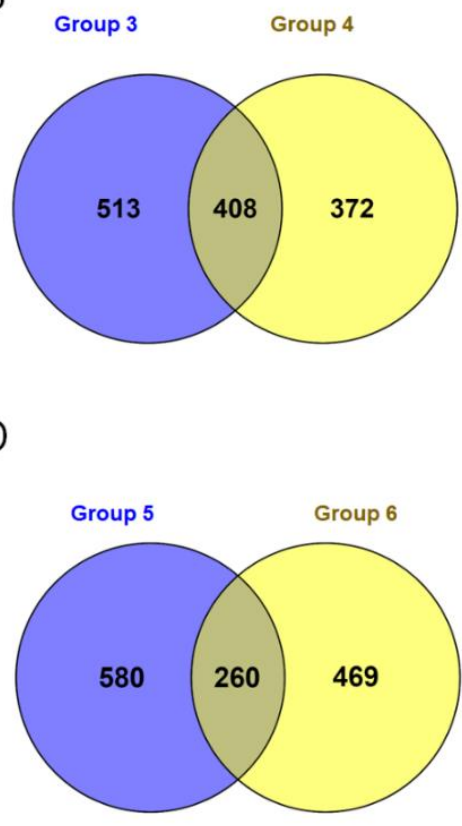

Figure 3. Differential expression of genes (DEGs) of groundnut genotype under control and infected conditions in response to Aspergillus flavus. (A) Group 1: moderately resistant J 11(I) vs. resistant (ICGV 91278, ICGV 91315, ICGV 93305, ICGV 91284, ICGV 94379, ICGV 91324) infected condition, Group 2: susceptible JL 24 vs. resistant (ICGV 91278, ICGV 91315, ICGV 93305, ICGV 91284, ICGV 94379, ICGV 91324) in infected condition, (B) Group 3: resistant J 11(C) vs. resistant (ICGV 91278, ICGV 91315, ICGV 93305, ICGV 91284, ICGV 94379, ICGV 91324) in control conditions, and group 4: susceptible JL 24 vs. resistant (ICGV 91278, ICGV 91315, ICGV 93305, ICGV 91284, ICGV 94379, ICGV 91324) under control conditions. (C) Number of differentially expressed transcripts between group 1, group 2, group 3 and group 4 and (D) group 5: susceptible JL 24 vs. (J 11, ICGV 91278, ICGV 91315, ICGV 93305, ICGV 91284, ICGV 94379, ICGV 91324 under control conditions, group 6: susceptible JL 24 vs. (J 11, ICGV 91278, ICGV 91315, ICGV 93305, ICGV 91284, ICGV 94379, ICGV 91324) in infected condition. 


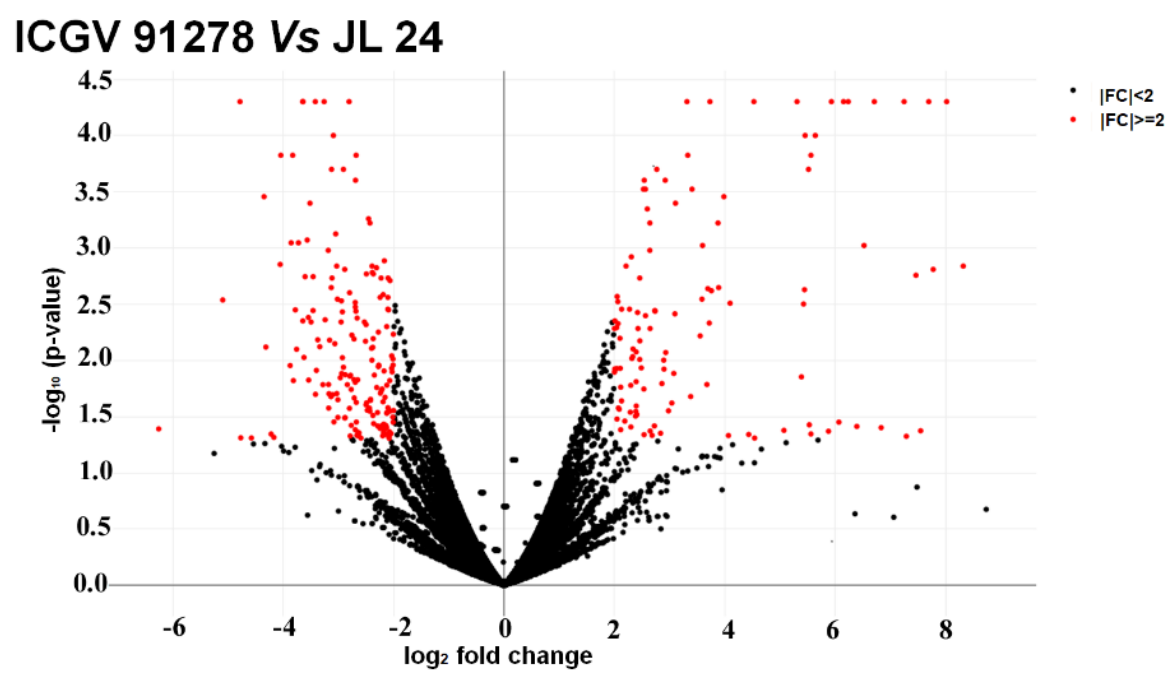

ICGV 91284 Vs JL 24

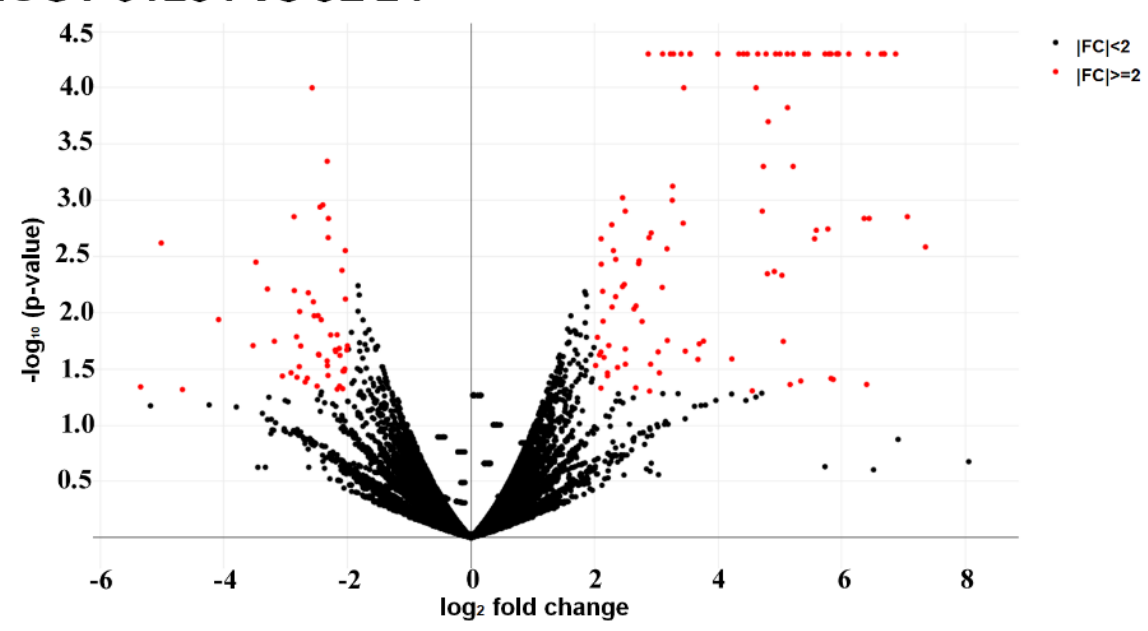

Figure 4. Volcano plot demonstrating the genes that were differentially expressed between susceptible (JL 24) and resistant genotypes (ICGV 91278, ICGV 91284) under infection conditions. Investigation and representation of DEGs were performed for developing Volcano plot. This plot is between $\log _{2}$ (fold change) and $-\log _{10}$ of the $p$-value on the $\mathrm{x}$-axis and $\mathrm{y}$-axis, respectively. Here, each dot is representing a gene and black and red coloured dots represent non-significant and significant genes, respectively.

\subsection{Functional Annotations and GO Assignment}

The putative functional annotation and GO terms were assigned to 56,239 transcripts using the NCBI non-redundant (nr) Viridiplantae protein database. Three categories were distinguished: biological processes (72.83\%), cellular processes (54.64\%), and molecular functions (83.09\%) (Figure 5; Table S2). In the cellular component category, cell, cell part, membrane and membrane part were the most important. Additionally, 7186 transcripts could be assigned and mapped to 138 different pathways in the KEGG information database (Table S3). The vast majority of the transcripts were mapped to the pathways related to purine metabolism (1063), thiamine metabolism (581), biosynthesis of antibiotics (546), and starch and sucrose metabolism (241). The complete list of pathways that were assigned to genes has been provided in the supplementary Table S3. This study identified 57 transcription factor (TF) families which include 6570 genes. The majority of these TFs were categorized into bHLH (719), MYB-related (479), NAC (437), and FAR1 family protein (320), among others. 


\section{A Cellular component}

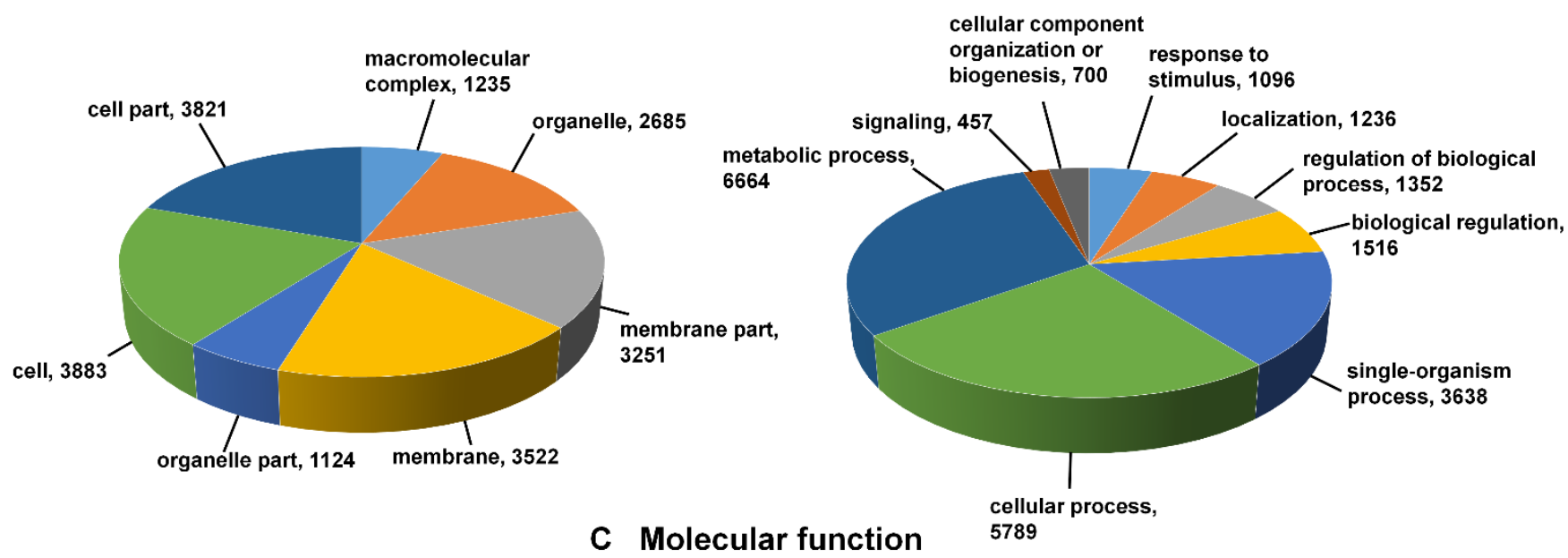

\section{B Biological process}

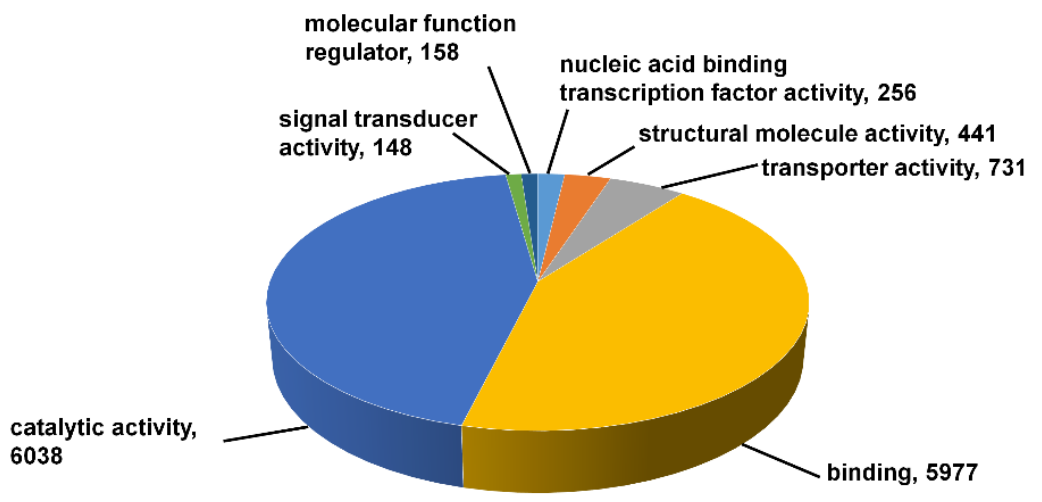

Figure 5. Distribution of gene ontology annotation assigned by Blast2 GO. This figure describes the three GO categories: cellular component (A), biological processes (B), and molecular functions (C).

\subsection{Spatial Transcript Expression and Identification of Transcription under Control and} Infected Conditions

A total of 4692 genes exhibited spatial transcript expression in 16 samples, including TF and non-TF encoding genes (Figure 6a). The largest numbers of sample specific transcripts were detected in ICGV 93305 (1533 genes), ICGV 91284 (762 genes), and ICGV 91324 (472 genes). Across samples, (38.75\%), ICGV 91284 (17.95\%) and ICGV 91324 (12.11\%) had the highest number of the TF encoding genes (Figure 6b), mostly dominant TFs like bHLH family proteins (719), ERF family proteins, and NAC family proteins. In resistant genotypes, the expressed TFs belonging to basic helix-loop-helix (bHLH) DNA-binding superfamily protein were the biggest group followed by MYB (479), NAC (437), and ERF (309) family proteins. In susceptible samples, GATA family proteins, MYB related family proteins, bHLH family proteins, and bZIP family proteins were the most significant group of expressed TFs. 


\section{A}
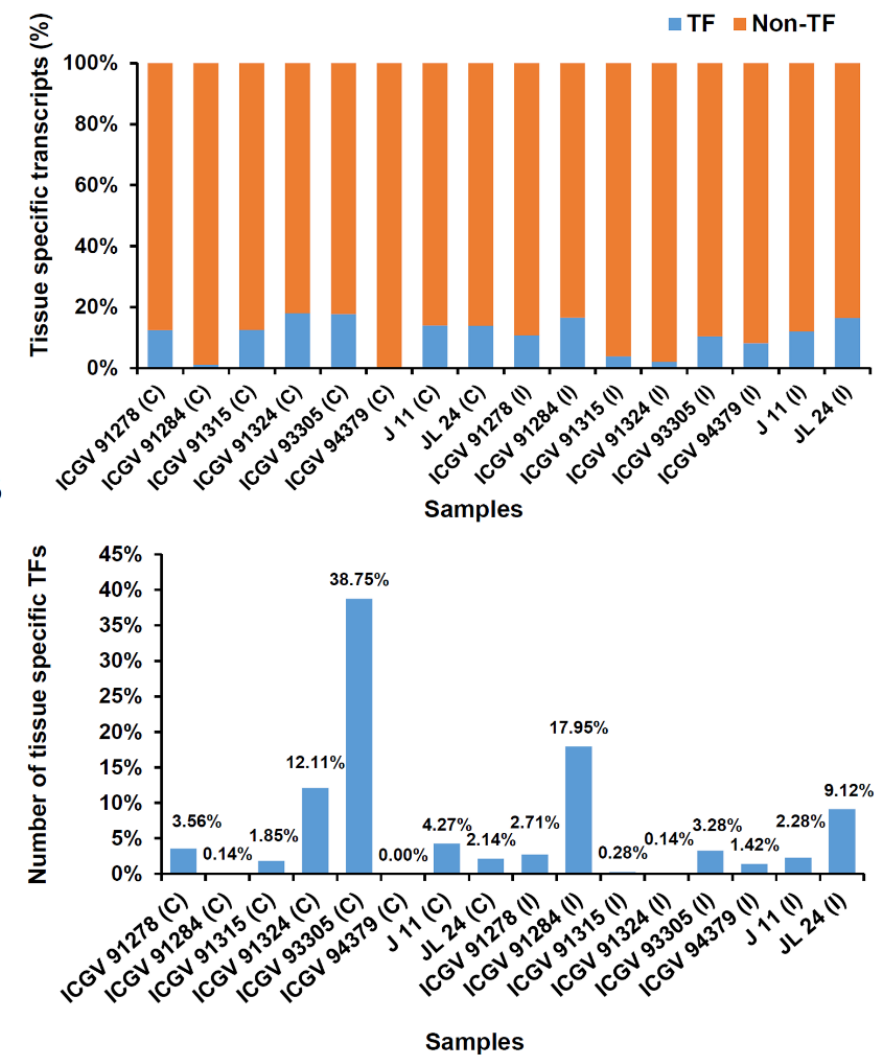

Figure 6. Spatial transcript expression identified in 16 samples. The figure shows the number of sample or genotype specific transcript in all 16 samples. Tissue specificity index $(\tau)$ was calculated to identify the genotype specific transcript. In the present study, transcripts with $\tau \geq 0.9$ were considered as sample specific. (A) Blue color represents sample specific transcript encoding transcription factors (TF) and orange color represents Non-TF transcripts. (B) The figure shows the distribution of sample specific transcript encoding transcription factors in all 16 samples.

\subsection{Pathways Genes Affecting during Host-Pathogen Interaction}

The pathway examination was performed to examine the molecular function of the DEGs/genes expressed during the host-pathogen interactions (Table S3). During the analysis, 7186 DEGs were mapped to 137 different pathways for aflatoxin infection. These pathways represent three different types of metabolic pathway, i.e., primary, secondary, and other metabolic pathways. The primary metabolic pathways mainly involve lipids, amino acids, carbohydrates, and vitamins. During this study, the most heavily influenced carbohydrate metabolism pathways included glycolysis, glyconeogenesis, glycogen metabolism, citric acid, starch and sugar metabolism. Likewise, the major lipid metabolism pathways affected during PAC contamination included fatty acid biosynthesis and degradation, sphingolipid metabolism and glycerolipid metabolism. Similarly, the most affected amino acid metabolic pathways during A. flavus infection included tyrosine, tryptophan, biosynthesis of phenylalanine, glutathione and several other pathways related to the metabolism of vitamins. Among secondary metabolism pathways, the most affected included carotenoids, steroids, flavonoids, cutin, and wax in addition to shikimate derivative dependent pathways. This shikimate derivative dependent pathway includes biosynthesis phenylpropanoid, flavonoid stilbenoid, diarylheptanoid, isoflavonoid, and cyanoamino acid metabolism. During PAC contamination and aflatoxin production, some selected pathways and their genes/DEGs were affected under both control and infected conditions (Figure 7). These important pathways include fatty acid biosynthesis, flavonoids biosynthesis, seed storage, sugar transport, resveratrol, seed linoleate, cell wall-related genes, ABA-responsive genes and 9-LOX related genes (Figure 8 and Table 2) (Table S4). 


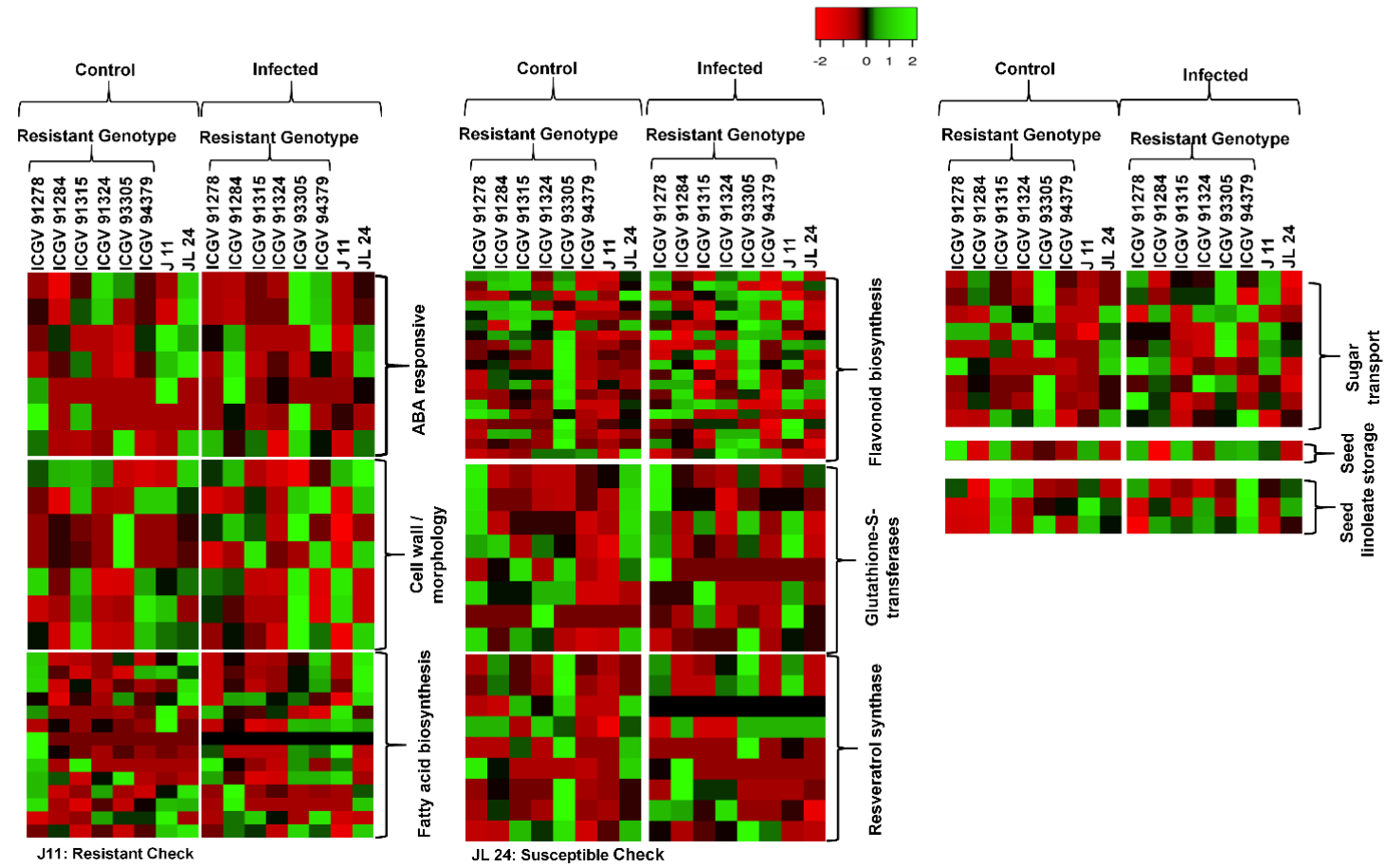

Figure 7. Heat map of different pathways of genes affected in 8 groundnut genotypes, both under control conditions and after infection with $A$. flavus. Some selected genes altered their expression in all of the pathways due to different pre-harvest aflatoxin contamination. Expression of genes involved in the glutathione-S-transferase, flavonoid biosynthesis, fatty acid biosynthesis, ABA responsive genes, resveratrol synthase, and seed linoleate gene expression is plotted. The color code corresponds to the FPKM value of the transcripts, increase from red to green. Genotype and treatment labels are shown at the top of the figure.

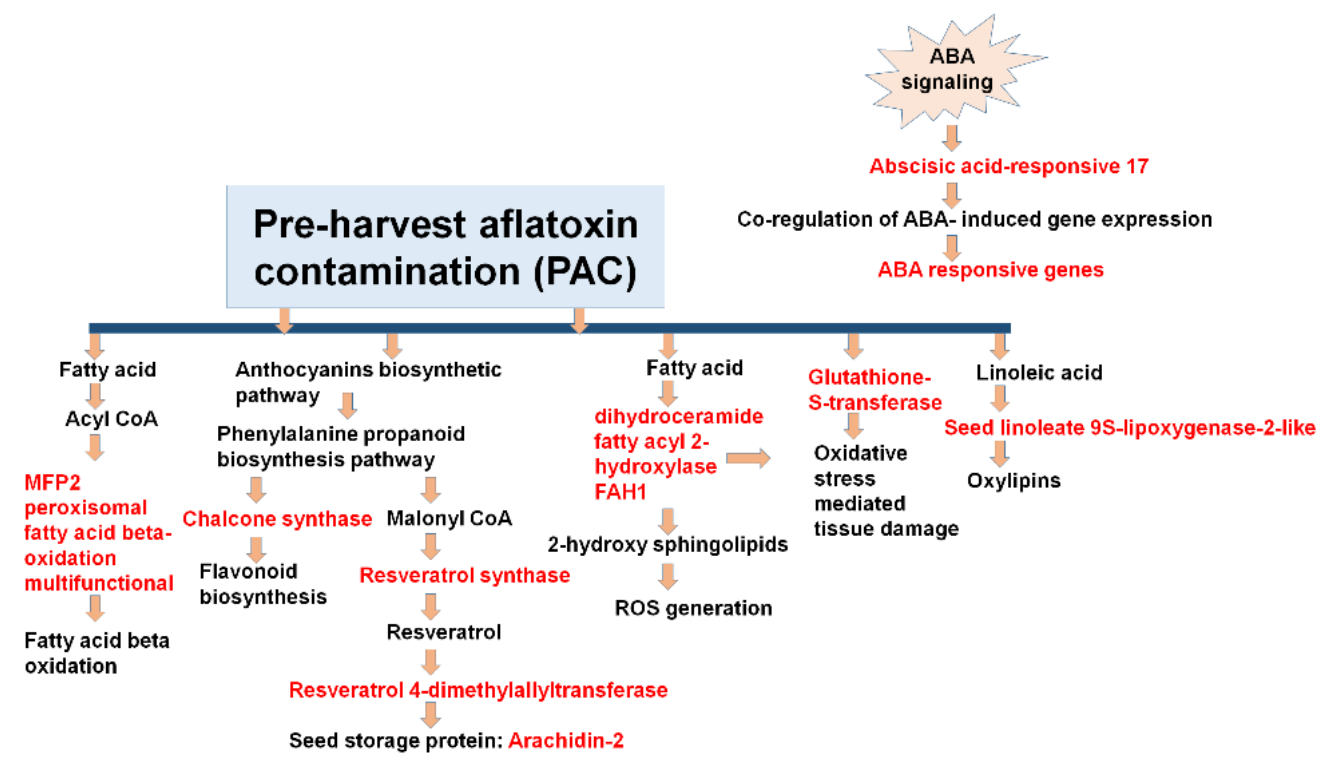

Stress responsive pathways and genes imparting resistance

Figure 8. PAC is largely facilitated by moisture and heat stress during pod development in a green house. The study indicated an ABA-responsive ABR17 gene belonging to the PR-10 class has been activated in plant-pathogen interactions during PAC. The components represented in red have an important role in host-pathogen interactions in this study, showing highly up-regulated patterns in resistant genotypes. Several pathways and TFs such as fatty acid biosynthesis, flavonoid biosynthesis, seed linoleate gene expression, resveratrol synthase, and glutathione-S-transferase play an important role in genetic resistance for PAC. The components in black represent the resistant pathways and other components which help in host-plant defense signaling. 
Table 2. Highly differentially expressed putative candidate genes for PAC in groundnut.

\begin{tabular}{|c|c|c|c|c|}
\hline \multirow{2}{*}{ Parents } & \multirow{2}{*}{ Gene ID } & \multirow{2}{*}{ Annotation } & \multicolumn{2}{|c|}{ Expression Values (FPKM) } \\
\hline & & & Control & Infection \\
\hline \multirow{3}{*}{ ICGV 91278} & UN_2125 & DEF2_Defensin 2 & 10520.9 & 20643 \\
\hline & ARP_1078 & Pathogenesis-related PR-4 isoform X2 & 44.09 & 102.03 \\
\hline & ARD_1670 & Pathogenesis-related 2-like & 16.54 & 84.08 \\
\hline \multirow{2}{*}{ ICGV 91284} & ARD_2757 & Probable BOI-related E3 ubiquitin-ligase 3 & 10.73 & 15.04 \\
\hline & ARP_15581 & Chalcone-flavonone isomerase $1 \mathrm{~A}$ & 6.84 & 3.29 \\
\hline ICGV 91315 & UN_4369 & ABA-responsive ABR17 & 16049.7 & 19023.1 \\
\hline \multirow{2}{*}{ ICGV 91324} & ARP_13077 & UDP-glucose flavonoid & 16.9 & 19.36 \\
\hline & ARD_12934 & UDP-glucose flavonoid & 19.36 & 24.95 \\
\hline \multirow{6}{*}{ ICGV 93305} & ARD_2757 & Probable BOI-related E3 ubiquitin-ligase 3 & 9.56 & 24.75 \\
\hline & ARP_1078 & Pathogenesis-related PR-4 isoform X2 & 47.09 & 128.9 \\
\hline & ARP_1913 & Probable BOI-related E3 ubiquitin- ligase 3 & 25.9 & 63.27 \\
\hline & ARP_24754 & ABA-responsive ABR17 & 11051.9 & 37685.6 \\
\hline & UN_2125 & DEF2_Defensin 2 & 3289.82 & 19092.1 \\
\hline & UN_4369 & ABA-responsive ABR17 & 16909.2 & 49108.9 \\
\hline \multirow{9}{*}{ ICGV 94379} & ARD_12934 & UDP-glucose flavonoid & 11.62 & 16.89 \\
\hline & ARP_13077 & UDP-glucose flavonoid & 8.54 & 15.55 \\
\hline & ARD_1670 & Pathogenesis-related 2-like & 5.58 & 10.62 \\
\hline & ARD_2757 & Probable BOI-related E3 ubiquitin-ligase 3 & 6.68 & 9.3 \\
\hline & ARP_1913 & Probable BOI-related E3 ubiquitin-ligase 3 & 59.65 & 84.48 \\
\hline & ARP_24754 & ABA-responsive ABR17 & 11532.5 & 27514.8 \\
\hline & UN_2125 & DEF2_Defensin 2 & 1995.02 & 6773.65 \\
\hline & UN_4369 & ABA-responsive ABR17 & 16056.3 & 35167.3 \\
\hline & ARD_13942 & NAD(P)H-dependent 6 -deoxychalcone synthase & 1.38 & 3.63 \\
\hline \multirow{12}{*}{$\mathrm{J} 11(\mathrm{R})$} & ARD_12934 & UDP-glucose flavonoid & 16.73 & 25.32 \\
\hline & ARP_13077 & UDP-glucose flavonoid & 7.83 & 24.47 \\
\hline & ARD_1670 & Pathogenesis-related 2-like & 2.2 & 49.04 \\
\hline & ARD_2757 & Probable BOI-related E3 ubiquitin-ligase 3 & 11.33 & 17.58 \\
\hline & ARP_1078 & Pathogenesis-related PR-4 isoform X2 & 0.54 & 30.46 \\
\hline & ARP_1913 & Probable BOI-related E3 ubiquitin- ligase 3 & 27.13 & 44.57 \\
\hline & ARP_24754 & ABA-responsive ABR17 & 9734.37 & 12586.6 \\
\hline & UN_2125 & DEF2_Defensin 2 & 1683.17 & 13333.2 \\
\hline & ARD_21521 & Chalcone-flavonone isomerase 2 & 0 & 1 \\
\hline & ARD_21522 & Chalcone-flavonone isomerase 1B-1 & 0 & 0.7 \\
\hline & ARP_15581 & Chalcone-flavonone isomerase $1 \mathrm{~A}$ & 2.28 & 4.82 \\
\hline & ARD_13942 & NAD(P)H-dependent 6 -deoxychalcone synthase & 2.19 & 4.64 \\
\hline
\end{tabular}

\section{Discussion}

The molecular mechanism correlated with the PAC mechanism is not yet clearly welldefined and the availability of high-quality reference genomes provides a great opportunity for improving our current understanding. A. flavus infection and aflatoxin production are reported to be controlled by a combination of factors like reactive oxygen species (ROS), LOX genes, carbohydrate and fatty acid biosynthesis pathway factors, defense proteins like pathogenesis related etc. [47-51]. In this context, by the transcriptomic profiling of the eight different resistant and one susceptible groundnut genotypes under control and infected conditions, the current examination yields a conclusive understanding of the molecular mechanisms involved with PAC in the seed.

Previous studies indicate that defense responses related to PAC mechanism is a multi-layered cycle which incorporates transcriptional control, the induction of various resistant genes, cell wall component factors, generation of ROS species, and PR related proteins that prompt opposition against pathogen attack. Many TFs, especially MYB and MYB related, bHLH, WRKY, NAC, AP2 TFs play vital roles in developing a defense mechanism [52]. Further, systemic acquired resistance (SAR) plays an essential role during 
the initial pathogen attack [53] and is also responsible for the expression of pathogenesisrelated proteins (PR-proteins) which directly act as a defense against various pests and pathogens [54]. Several pathways play an important role in providing defense reactions against pathogen attack and these pathways might be salicylic acid (SA), jasmonic acid (JA) and ethylene signaling [55]. These pathways play a vital role during signaling regulation.

The current investigation distinguished around 137 non-redundant pathways that were influenced by the 7186 DEGs, contributing to various pathways like pyruvate metabolism (169), fatty acid biosynthesis (61), TCA cycle (79), aflatoxin biosynthesis (21), glycolysis/gluconeogenesis (17), starch, and sucrose metabolism (241). Carbohydrate, fatty acid and amino acid metabolism are the primary metabolic pathways that are substantially affected. It was reported that glucose and carbohydrates are considered as an excellent substrate for both fungal growth and AF production [15]. Glucose is the supported carbon hotspot for A. flavus; therefore, it controls sucrose hydrolyzing enzymes that promote the A. flavus infection by providing a consistent stock of supplements to the pathogen [56]. The previous studies suggested that pathogens create a favorable environment for their development by manipulating the metabolism of crops [57]. In A. flavus infected maize, two core pathways such as starch degradation and hexose mobilization were reported [58].

Pathogenesis-related proteins (PR proteins) play significant roles in the plant's defense system [59]. The defensins are commonly antimicrobial peptides that have been associated with plants, and guard against different microbial assaults by collaborating with membrane multi-layer lipids for their natural action [60]. After the induction of infection, PR genes are activated and subsequently produce PR proteins. In the infected seeds, the expression of the pathogenesis-related 2-like gene (ARD_1670) and pathogenesis-related PR-4 isoform X2 (ARP_1078) showed up-regulation in the resistant genotypes (ICGV 91278, ICGV 94379, J 11) of groundnut seed, while the reverse was true under control conditions.

Similarly, for defensin genes in infected seeds, the expression of the defensin 1 protein (UN_2125) showed up-regulation in the resistant genotypes (ICGV 91278, ICGV 93305, ICGV 94379, J 11) of groundnut seed while the reverse was true under control conditions. Similarly, for defensin-2, under control conditions, the expression of the defensin 2 protein (UN_4369) showed up-regulation in the resistant genotypes (ICGV 91315, ICGV 93305, ICGV 94379) of groundnut seed while the reverse was true under normal conditions. A recent report also suggested significant reductions in aflatoxin production through a host-induced gene silencing (HIGS) approach by overexpressing antifungal defensins genes (MsDef1 and MtDef4.2) (aflM and aflP) from the aflatoxin biosynthetic pathway in groundnut [61], indicating the importance of these genes in defense against $A$. flavus and the importance of deploying of genomic variation for crop improvement.

On the other hand, the flavonoids are phenylalanine-derived secondary metabolites that play a significant role in contributing to resistance against pathogens [62] and are also known to detoxify ROS produced by pathogens and the plant during infection [63]. Flavonoid biosynthesis pathways include the production of chalcone synthesized by $\mathrm{CHS}$, $N A D(P) H$-dependent 6-deoxychalcone synthase, and chalcone isomerase. Here, we observed that the expression of CHS genes and chalcone-flavanone isomerase proteins during $A$. flavus infection was higher in the resistant genotype (J 11) as compared to JL 24 (susceptible genotype). In the infected seeds, the expression of chalcone isomerase (ARD_21521, ARD_21522, ARP_15581) and NAD(P)H-dependent 6-deoxychalcone synthase (ARD_13942, ARD_19144) showed up-regulation in the resistant genotype of groundnut seed while it the reverse was true under control conditions. The CHS protein was also found to be involved in salicylic acid signaling pathways during plant safeguard responses [64]. The expression of $\mathrm{CHS}$ is higher in resistant genotypes as compared to susceptible genotypes. Similar observations were made while studying the resistance mechanisms for in vitro seed colonization (IVSC) and aflatoxin production (AP) of A. flavus in the groundnut $[9,65]$ which showed interconnection between different resistance mechanisms.

UDP-glucose flavonoid 3-O-glucosyltransferase 3 is a protein involved in the biosynthesis of secondary metabolites [66]. It plays an important role in anthocyanin biosynthesis 
and phenylpropanoid pathways. Probably, BOI-related E3 ubiquitin-ligase 3 plays a vital role in plant defense response mechanisms [67]. Under control conditions the expression of UDP-glucose flavonoid 3-O-glucosyltransferase 3 (ARD_12934, ARP_13077) showed down-regulation in the resistant genotypes (ICGV 94379, ICGV 91324, J 11) as compared to the susceptible genotype (JL 24) while in infected seeds, the expression of UDP-glucose flavonoid 3-O-glucosyltransferase 3 showed up-regulation in the resistant genotypes (ICGV 94379, ICGV 91324, J 11) of groundnut seed as compared to the susceptible genotype (JL 24).

Under control conditions, the expression of the BRG3 (Probable BOI-related E3 ubiquitin- ligase 3) gene (ARD_2757, ARP 1913) showed down-regulation in the resistant genotypes (ICGV 91284, ICGV 93305, ICGV 94379, J 11) as compared to the susceptible genotype (JL 24) while in infected seeds, the expression of probable BOI-related E3 ubiquitin-ligase 3 showed up-regulation in the resistant genotypes (ICGV 91284, ICGV 93305, ICGV 94379, J 11) of groundnut seed as compared to the susceptible genotype (JL 24).

Aflatoxin is mainly produced by the utilization of fatty acid biosynthesis and sugar utilization through acetyl CoA and malonyl-CoA pathways through glucose catabolism [68]. Oxylipins, produced by oxygenase enzymes, regulate signaling pathways in fungi and also play a role during conidial growth in fungi [69]. In the infected seeds, the expression of oxylipin (ARD_10525 and ARP_3974) showed up-regulation in these resistant genotypes (ICGV 91278, ICGV 91324, and J 11) of groundnut as compared to JL 24, while it was the reverse under control conditions. These fatty acids also serve as key molecules that are engaged in plant defense in the development of cuticular elements and phytohormone jasmonic acids (JA). The immediate roles of fatty acids in plant defense have also been shown by modulating the response of basal, effector-triggered and systemic immunity [70]. Secondary metabolic pathways that include terpenoids, flavonoids, and steroid biosynthesis pathways have additionally been demonstrated to be influenced during the Aspergillus infection. Their role in plant defense is mostly related to their strong anti-oxidative properties.

The $A B R 1$ ethylene-responsive transcription factor is a significant factor because it is an ABA response repressor [71]. In the infected seeds, the expression of ABA-responsive ABR17 (ARP_24754 and UN_4369) exhibited high-regulation patterns in resistant genotypes (ICGV 93305, ICGV 94379, and J 11) as compared to JL 24 (susceptible genotype), while under control conditions this gene showed down-regulation patterns in all the resistant genotypes of groundnut seeds. ABA interacts with FUSCA3 which in turn regulates fatty acid biosynthesis and oil production [72,73]. The high expression in aflatoxin-contaminated seeds indicates that this gene is a candidate susceptibility factor for contamination before harvest. This finding is reinforced by the parallel observation that ABA signals repressed by this gene were also down-regulated in contaminated groundnut seeds. A previous study also highlighted the importance of the two pathways fatty acid biosynthesis and abscisic acid (ABA) in addition to the susceptibility factor ABR1 as a repressor of ABA signaling, in permitting PAC [39].

In summary, this study provided a deeper understanding of the molecular mechanism for pre-harvest aflatoxin contamination in groundnut in addition to the complex molecular interaction between groundnut and A.flavus. This study provided insights into the different genes and pathways that play key roles in inducing plant defense mechanisms for PAC resistance in groundnut. It has been clearly observed how several DEGs were activated or repressed by $A$. flavus infection in group 2 (ICGV 91284) and 3 (ICGV 91284, ICGV 91315, ICGV 93305, ICGV 94379); more DEGs were up-regulated in group 1 (ICGV 91278) than in group 2 (ICGV 91284) at every time point. More importantly, several genes/pathways were found highly up-regulated in PAC (pre-harvest aflatoxin contamination) mechanisms in infected seeds. It is important to note that several biotic and abiotic stresses such as insect and nematode damage, drought and heat stress, poor cultural and farming practices exacerbate PAC and affect pod yield and quality in the field. In response, several resistant genes were either up-regulated or down-regulated to combat the $A$. flavus infection in the 
field. This study also indicated the vital role of ABA-responsive $A B R 17$, which co-regulates the genes of $\mathrm{ABA}$ responsive elements during drought stress, in providing resistance against $A$. flavus infection. It belongs to the PR-10 class and is also involved in several plant-pathogen interactions. Several other biotic and abiotic stress components activated several pathways and TFs such as fatty acid biosynthesis, flavonoid biosynthesis, seed lineolate gene expression, chalcone synthase, 9s-LOX, resveratrol synthase, and glutathioneS-transferase; defense related-genes which play important roles in genetic resistance to PAC. These genes were highly up-regulated in the resistant genotype controlling PAC resistance. These genes and pathways were working in a co-regulated manner to provide resistance against $A$. flavus infection, and can be used for enhancing PAC resistance through genomics-assisted breeding.

Supplementary Materials: The following are available online at https: / www.mdpi.com/article/ 10.3390/jof7060413/s1. Table S1: Expression values ( $\log _{2}$ transformed FPKM) of genes expressed in 16 samples, Table S2: GO of biological process, molecular function and cellular function in genes expressed in 16 samples, Table S3: List of pathways identified in KEGG database, Table S4: Important pathways controlling PAC in groundnut.

Author Contributions: R.K.V. conceptualized the idea and supervised the project. A.K.P. together with S.N.N., H.K.S., M.K.P. and S.P. conducted the experiments. P.S. (Pooja Soni), A.K.P., P.T. and P.B. contributed to data analysis. P.S. (Pooja Soni), A.K.P., M.K.P., P.S. (Prashant Singam), J.C.F. and B.G. contributed to the interpretation of the data. P.S. (Pooja Soni) coordinated drafting the manuscript together with A.K.P., M.K.P., S.N.N., J.C.F., B.G. and R.K.V. All authors have read and agreed to the published version of the manuscript.

Funding: The authors are grateful to MARS-Wrigley, the USA, the CGIAR-Natural Science Foundation of China (NSFC), China, and the Bill \& Melinda Gates Foundation for supporting this study in part. Pooja Soni is thankful to the Council of Scientific \& Industrial Research (CSIR) and the Government of India for the CSIR-Junior/Senior Research Fellowship. R.K.V. is thankful to the Science and Engineering Research Board (SERB), the Department of Science and Technology (DST), and the Government of India for the JC Bose National Fellowship.

Institutional Review Board Statement: Not applicable.

Informed Consent Statement: Not applicable.

Data Availability Statement: All sequencing data generated have been deposited into National Center for Biotechnology Information (NCBI) Sequence Read Archive (SRA) database under the BioProject ID: PRJNA732524.

Acknowledgments: We thank Ashwin Jayale and U. Naga Mangala for the technical support given during glass house experiments and aflatoxin estimation.

Conflicts of Interest: The authors declare there is no conflict of interest.

\section{References}

1. Perrone, G.; Haidukowski, M.; Stea, G.; Epifani, F.; Bandyopadhyay, R.; Leslie, J.F.; Logrieco, A. Population structure and Aflatoxin production by Aspergillus Sect. Flavi from maize in Nigeria and Ghana. Food Microbiol. 2014, 41, 52-59. [CrossRef] [PubMed]

2. Pandey, M.K.; Kumar, R.; Pandey, A.K.; Soni, P.; Gangurde, S.S.; Sudini, H.K.; Fountain, J.C.; Liao, B.; Desmae, H.; Okori, P.; et al. Mitigating aflatoxin contamination in groundnut through a combination of genetic resistance and post-harvest management practices. Toxins 2019, 11, 315. [CrossRef]

3. Gong, Y.; Hounsa, A.; Egal, S.; Turner, P.C.; Sutcliffe, A.E.; Hall, A.J.; Cardwell, K.; Wild, C.P. Postweaning exposure to aflatoxin results in impaired child growth: A longitudinal study in Benin, West Africa. Environ. Health Perspect. 2004, 112, 1334-1338. [CrossRef] [PubMed]

4. Sahoo, P.; Mukherjee, S. Effect of dietary $\beta-1,3$ glucan on immune responses and disease resistance of healthy and aflatoxin B1-induced immunocompromised rohu (Labeo rohita Hamilton). Fish Shellfish. Immunol. 2001, 11, 683-695. [CrossRef] [PubMed]

5. Jolly, P.E. Aflatoxin: Does it contribute to an increase in HIV viral load? Future Microbiol. 2014, 9, 121-124. [CrossRef] [PubMed]

6. Wild, C.P.; Montesano, R. A model of interaction: Aflatoxins and hepatitis viruses in liver cancer aetiology and prevention. Cancer Lett. 2009, 286, 22-28. [CrossRef] 
7. Strosnider, H.; Azziz-Baumgartner, E.; Banziger, M.; Bhat, R.V.; Breiman, R.; Brune, M.-N.; Decock, K.; Dilley, A.; Groopman, J.; Hell, K.; et al. Workgroup report: Public health strategies for reducing aflatoxin exposure in developing countries. Environ. Health Perspect. 2006, 114, 1898-1903. [CrossRef]

8. Benkerroum, N. Chronic and acute toxicities of aflatoxins: Mechanisms of action. Int. J. Environ. Res. Public Health 2020, 17, 423. [CrossRef]

9. Nayak, S.N.; Agarwal, G.; Pandey, M.K.; Sudini, H.K.; Jayale, A.S.; Purohit, S.; Desai, A.; Wan, L.; Guo, B.; Liao, B.; et al. Aspergillus flavus infection triggered immune responses and host-pathogen cross-talks in groundnut during in-vitro seed colonization. Sci. Rep. 2017, 7, 1-14. [CrossRef]

10. Soni, P.; Gangurde, S.S.; Ortega-Beltran, A.; Kumar, R.; Parmar, S.; Sudini, H.K.; Lei, Y.; Ni, X.; Huai, D.; Fountain, J.C.; et al. Functional biology and molecular mechanisms of host-pathogen interactions for aflatoxin contamination in groundnut (Arachis hypogaea L.) and maize (Zea mays L.). Front. Microbiol. 2020, 11, 227. [CrossRef]

11. Upadhyaya, H.D.; Nigam, S.N.; Thakur, R.P. Genetic enhancement for resistance to aflatoxin contamination in groundnut. In Proceedings of the Seventh ICRISAT Regional Groundnut Meeting for Western and Central Africa, Cotonu, Benin, 6-8 December 2000; International Crops Research Institute for the Semi-Arid Tropics: Patancheru, India, 2002; pp. 29-36.

12. Waliyar, F.; Kumar, P.L.; Traoré, A.; Ntare, B.R.; Diarra, B.; Kodio, O. Pre and post-harvest management of aflatoxin contamination in peanuts. In Mycotoxins: Detection Methods, Management, Public Health and Agricultural Trade; Leslie, J.F., Bandyopadhyay, R., Visconti, A., Eds.; CABI: Wallingford, UK, 2008; pp. 209-218.

13. Waliyar, F.; Umeh, V.; Traore, A.; Osiru, M.; Ntare, B.; Diarra, B.; Kodio, O.; Kumar, K.V.K.; Sudini, H. Prevalence and distribution of aflatoxin contamination in groundnut (Arachis hypogaea L.) in Mali, West Africa. Crop Prot. 2015, 70, 1-7. [CrossRef]

14. Guo, B.; Chen, Z.-Y.; Lee, R.D.; Scully, B.T. Drought stress and preharvest aflatoxin contamination in agricultural commodity: Genetics, genomics and proteomics. J. Integr. Plant Biol. 2008, 50, 1281-1291. [CrossRef] [PubMed]

15. Fountain, J.C.; Khera, P.; Yang, L.; Nayak, S.N.; Scully, B.T.; Lee, R.D.; Chen, Z.-Y.; Kemerait, R.C.; Varshney, R.; Guo, B. Resistance to Aspergillus flavus in maize and peanut: Molecular biology, breeding, environmental stress, and future perspectives. Crop J. 2015, 3, 229-237. [CrossRef]

16. Holbrook, C.C.; Kvien, C.K.; Rucker, K.S.; Wilson, D.M.; Hook, J.E.; Matheron, M.E. Preharvest aflatoxin contamination in drought-tolerant and drought-intolerant peanut genotypes1. Peanut Sci. 2000, 27, 45-48. [CrossRef]

17. Nigam, S.N.; Waliyar, F.; Aruna, R.; Reddy, S.V.; Kumar, P.L.; Craufurd, P.Q.; Diallo, A.T.; Ntare, B.R.; Upadhyaya, H.D. Breeding peanut for resistance to aflatoxin contamination at ICRISAT. Peanut Sci. 2009, 36, 42-49. [CrossRef]

18. Girdthai, T.; Jogloy, S.; Vorasoot, N.; Akkasaeng, C.; Wongkaew, S.; Holbrook, C.C.; Patanothai, A. Associations between physiological traits for drought tolerance and aflatoxin contamination in peanut genotypes under terminal drought. Plant Breed. 2010, 129, 693-699. [CrossRef]

19. Dorner, J.W.; Cole, R.J.; Sanders, T.H.; Blankenship, P.D. Interrelationship of kernel water activity, soil temperature, maturity, and phytoalexin production in pre-harvest aflatoxin contamination of drought-stressed peanuts. Mycopathology 1989, 105, 117-128 [CrossRef]

20. Waliyar, F.; Traoré, A.; Fatondji, D.; Ntare, B.R. Effect of irrigation interval, planting date, and cultivar on Aspergillus flavus and aflatoxin contamination of peanut in a sandy soil of Niger. Peanut Sci. 2003, 30, 79-84. [CrossRef]

21. Clevenger, J.; Marasigan, K.; Liakos, V.; Sobolev, V.; Vellidis, G.; Holbrook, C.; Ozias-Akins, P. RNA sequencing of contaminated seeds reveals the state of the seed permissive for pre-harvest aflatoxin contamination and points to a potential susceptibility factor. Toxins 2016, 8, 317. [CrossRef]

22. Martin, J.A.; Wang, Z. Next-generation transcriptome assembly. Nat. Rev. Genet. 2011, 12, 671-682. [CrossRef]

23. Payton, P.; Kottapalli, K.R.; Rowland, D.; Faircloth, W.; Guo, B.; Burow, M.; Puppala, N.; Gallo, M. Gene expression profiling in peanut using high density oligonucleotide microarrays. BMC Genom. 2009, 10, 265. [CrossRef] [PubMed]

24. Guo, B.; Fedorova, N.D.; Chen, X.; Wan, C.-H.; Wang, W.; Nierman, W.C.; Bhatnagar, D.; Yu, J. Gene expression profiling and identification of resistance genes to Aspergillus flavus infection in peanut through EST and microarray strategies. Toxins 2011, 3, 737-753. [CrossRef] [PubMed]

25. Zhang, J.; Liang, S.; Duan, J.; Wang, J.; Chen, S.; Cheng, Z.; Li, Y. De novo assembly and characterization of the transcriptome during seed development, and generation of genic-SSR markers in peanut (Arachis hypogaea L.). BMC Genom. 2012, 13, 90. [CrossRef]

26. Xia, H.; Zhao, C.; Hou, L.; Li, A.; Zhao, S.; Bi, Y.; An, J.; Zhao, Y.; Wan, S.; Wang, X. Transcriptome profiling of peanut gynophores revealed global reprogramming of gene expression during early pod development in darkness. BMC Genom. $2013,14,517$. [CrossRef] [PubMed]

27. Wang, H.; Lei, Y.; Wan, L.; Yan, L.; Lv, J.; Dai, X.; Ren, X.; Guo, W.; Jiang, H.; Liao, B. Comparative transcript profiling of resistant and susceptible peanut post-harvest seeds in response to aflatoxin production by Aspergillus flavus. BMC Plant Biol. 2016, 16, 1-16. [CrossRef]

28. Bertioli, S.C.M.L.; Cannon, S.B.; Froenicke, L.; Huang, G.; Farmer, A.D.; Cannon, E.K.S.; Liu, X.; Gao, D.; Clevenger, J.; Dash, S.; et al. The genome sequences of Arachis duranensis and Arachis ipaensis, the diploid ancestors of cultivated peanut. Nat. Genet. 2016, 48, 438-446. [CrossRef] [PubMed] 
29. Chen, X.; Li, H.; Pandey, M.K.; Yang, Q.; Wang, X.; Garg, V.; Li, H.; Chi, X.; Doddamani, D.; Hong, Y.; et al. Draft genome of the peanut A-genome progenitor (Arachis duranensis) provides insights into geocarpy, oil biosynthesis, and allergens. Proc. Natl. Acad. Sci. USA 2016, 113, 6785-6790. [CrossRef] [PubMed]

30. Bertioli, D.J.; Jenkins, J.; Clevenger, J.; Dudchenko, O.; Gao, D.; Seijo, G.; Leal-Bertioli, S.C.M.; Ren, L.; Farmer, A.D.; Pandey, M.K.; et al. The genome sequence of segmental allotetraploid peanut Arachis hypogaea. Nat. Genet. 2019, 51, 877-884. [CrossRef]

31. Chen, X.; Lu, Q.; Liu, H.; Zhang, J.; Hong, Y.; Lan, H.; Li, H.; Wang, J.; Liu, H.; Li, S.; et al. Sequencing of cultivated peanut, Arachis hypogaea, yields insights into genome evolution and oil improvement. Mol. Plant 2019, 12, 920-934. [CrossRef]

32. Zhuang, W.; Chen, H.; Yang, M.; Wang, J.; Pandey, M.K.; Zhang, C.; Chang, W.C.; Zhang, L.; Zhang, X.; Tang, R.; et al. The Arachis hypogaea genome elucidates legume karyotypes, polyploid evolution and crop domestication. Nat. Genet. 2019, 51, 865-876. [CrossRef]

33. Varshney, R.K.; Pandey, M.K.; Bohra, A.; Singh, V.K.; Thudi, M.; Saxena, R.K. Toward the sequence-based breeding in legumes in the post-genome sequencing era. Theor. Appl. Genet. 2019, 132, 797-816. [CrossRef]

34. Pandey, M.K.; Pandey, A.K.; Kumar, R.; Nwosu, V.; Guo, B.; Wright, G.; Bhat, R.S.; Chen, X.; Bera, S.K.; Yuan, M.; et al. Translational genomics for achieving higher genetic gains in post-genome era in groundnut. Theor. Appl. Genet. 2020, 133, 1679-1702. [CrossRef]

35. Pandey, M.K.; Roorkiwal, M.; Singh, V.; Lingam, A.; Kudapa, H.; Thudi, M.; Chitikineni, A.; Rathore, A.; Varshney, R.K. Emerging genomic tools for legume breeding: Current status and future perspectives. Front. Plant Sci. 2016, 7, 455. [CrossRef]

36. Waliyar, F.; Reddy, S.V.; Kumar, P.L. Estimation of Aspergillus flavus infection and aflatoxin contamination in seeds. In Laboratory Manual; International Crops Research Institute for the Semi-Arid Tropics: Patancheru, India, 2005; pp. $26-27$.

37. Katta, M.A.V.S.K.; Khan, A.W.; Doddamani, D.; Thudi, M.; Varshney, R.K. NGS-QCbox and Raspberry for parallel, automated and rapid quality control analysis of large-scale next generation sequencing (Illumina) data. PLoS ONE 2015, 10, e0139868. [CrossRef]

38. Bolger, A.M.; Lohse, M.; Usadel, B. Trimmomatic: A flexible trimmer for Illumina sequence data. Bioinformatics 2014, 30, 2114-2120. [CrossRef] [PubMed]

39. Clevenger, J.P.; Chu, Y.; Scheffler, B.; Ozias-Akins, P. A Developmental transcriptome map for allotetraploid Arachis hypogaea. Front. Plant Sci. 2016, 7, 1446. [CrossRef] [PubMed]

40. Kim, D.; Pertea, G.; Trapnell, C.; Pimentel, H.; Kelley, R.; Salzberg, S.L. TopHat2: Accurate alignment of transcriptomes in the presence of insertions, deletions and gene fusions. Genome Biol. 2013, 14, R36. [CrossRef]

41. Grabherr, M.G.; Haas, B.J.; Yassour, M.; Levin, J.Z.; Thompson, D.A.; Amit, I.; Adiconis, X.; Fan, L.; Raychowdhury, R.; Zeng, Q.; et al. Trinity: Reconstructing a full-length transcriptome without a genome from RNA-Seq data. Nat. Biotechnol. 2011, $29,644$. [CrossRef] [PubMed]

42. Gilbert, D. EvidentialGene: Tr2aacds, Mrna Transcript Assembly Software. 2013. Available online: http://arthropods.eugenes. org/EvidentialGene (accessed on 27 July 2020).

43. Trapnell, C.; Williams, B.A.; Pertea, G.; Mortazavi, A.; Kwan, G.; Van Baren, M.J.; Salzberg, S.L.; Wold, B.J.; Pachter, L. Transcript assembly and quantification by RNA-Seq reveals unannotated transcripts and isoform switching during cell differentiation. Nat. Biotechnol. 2010, 28, 511-515. [CrossRef]

44. Conesa, A.; Götz, S.; García-Gómez, J.M.; Terol, J.; Talón, M.; Robles, M. Blast2GO: A universal tool for annotation, visualization and analysis in functional genomics research. Bioinformatics 2005, 21, 3674-3676. [CrossRef]

45. Yanai, I.; Benjamin, H.; Shmoish, M.; Chalifa-Caspi, V.; Shklar, M.; Ophir, R.; Bar-Even, A.; Horn-Saban, S.; Safran, M.; Domany, E.; et al. Genome-wide midrange transcription profiles reveal expression level relationships in human tissue specification. Bioinformatics 2004, 21, 650-659. [CrossRef] [PubMed]

46. Jin, J.; Zhang, H.; Kong, L.; Gao, G.; Luo, J. PlantTFDB 3.0: A portal for the functional and evolutionary study of plant transcription factors. Nucleic Acids Res. 2014, 42, D1182-D1187. [CrossRef] [PubMed]

47. Jayashree, T.; Subramanyam, C. Oxidative stress as a prerequisite for aflatoxin production by Aspergillus parasiticus. Free Radic. Biol. Med. 2000, 29, 981-985. [CrossRef]

48. Bhattacharjee, S. Reactive oxygen species and oxidative burst: Roles in stress, senescence and signal transducation in plants. Curr. Sci. 2005, 89, 1113-1121.

49. Roze, L.V.; Hong, S.-Y.; Linz, J.E. Aflatoxin biosynthesis: Current frontiers. Annu. Rev. Food Sci. Technol. $2013,4,293-311$. [CrossRef] [PubMed]

50. Yang, L.; Fountain, J.C.; Wang, H.; Ni, X.; Ji, P.; Lee, R.D.; Kemerait, R.C.; Scully, B.T.; Guo, B. Stress sensitivity is associated with differential accumulation of reactive oxygen and nitrogen species in maize genotypes with contrasting levels of drought tolerance. Int. J. Mol. Sci. 2015, 16, 24791-24819. [CrossRef]

51. Yang, L.; Fountain, J.C.; Chu, Y.; Ni, X.; Lee, R.D.; Kemerait, R.C.; Guo, B. Differential accumulation of reactive oxygen and nitrogen species in maize lines with contrasting drought tolerance and aflatoxin resistance. Phytopathology 2016, 106, S2.16.

52. Singh, K.B.; Foley, R.C.; Oñate-Sánchez, L. Transcription factors in plant defense and stress responses. Curr. Opin. Plant Biol. 2002, 5, 430-436. [CrossRef]

53. Durrant, W.; Dong, X. Systemic acquired resistance. Annu. Rev. Phytopathol. 2004, 42, 185-209. [CrossRef]

54. Mandal, P. An overview of systemic acquired resistance (sar), a signal transduction pathway of plant defense. Rev. Res. 2019, 8, $1-7$. 
55. Kunkel, B.N.; Brooks, D.M. Cross talk between signaling pathways in pathogen defense. Curr. Opin. Plant Biol. $2002,5,325-331$. [CrossRef]

56. Fountain, J.C.; Bajaj, P.; Nayak, S.N.; Yang, L.; Pandey, M.K.; Kumar, V.; Jayale, A.S.; Chitikineni, A.; Lee, R.D.; Kemerait, R.C.; et al. Responses of Aspergillus flavus to oxidative stress are related to fungal development regulator, antioxidant enzyme, and secondary metabolite biosynthetic gene expression. Front. Microbiol. 2016, 7, 2048. [CrossRef]

57. Doehlemann, G.; Ökmen, B.; Zhu, W.; Sharon, A. Plant pathogenic fungi. Mycologia 2017, 79, 1-23.

58. Dolezal, A.L.; Eshu, X.; Obrian, G.R.; Nielsen, D.; Woloshuk, C.P.; Boston, R.S.; Payne, G.A. Aspergillus flavus infection induces transcriptional and physical changes in developing maize kernels. Front. Microbiol. 2014, 5, 384. [CrossRef]

59. Jiang, L.; Wu, J.; Fan, S.; Li, W.; Dong, L.; Cheng, Q.; Xu, P.; Zhang, S. Isolation and characterization of a novel pathogenesis-related protein gene (GmPRP) with induced expression in soybean (Glycine max) during Infection with Phytophthora sojae. PLoS ONE 2015, 10, e0129932. [CrossRef] [PubMed]

60. Bala, M.; Radhakrishnan, T.; Kumar, A.; Mishra, G.P.; Dobraia, J.R.; Kirti, P.B. Erratum: Overexpression of a fusion defensin gene from radish and fenugreek improves resistance against leaf spot diseases caused by Cercospora arachidicola and Phaeoisariopsis personata in peanut. Turk. J. Boil. 2019, 43, 154. [CrossRef] [PubMed]

61. Sharma, K.K.; Pothana, A.; Prasad, K.; Shah, D.; Kaur, J.; Bhatnagar, D.; Chen, Z.-Y.; Raruang, Y.; Cary, J.W.; Rajasekaran, K.; et al. Peanuts that keep aflatoxin at bay: A threshold that matters. Plant Biotechnol. J. 2017, 16, 1024-1033. [CrossRef]

62. Liu, J.; Osbourn, A.; Ma, P. MYB Transcription factors as regulators of phenylpropanoid metabolism in plants. Mol. Plant 2015, 8, 689-708. [CrossRef] [PubMed]

63. Mierziak, J.; Kostyn, K.; Kulma, A. Flavonoids as important molecules of plant interactions with the environment. Molecules 2014, 19, 16240-16265. [CrossRef]

64. Dao, T.T.H.; Linthorst, H.J.M.; Verpoorte, R. Chalcone synthase and its functions in plant resistance. Phytochem. Rev. 2011, 10, 397-412. [CrossRef]

65. Soni, P.; Nayak, S.N.; Kumar, R.; Pandey, M.K.; Singh, N.; Sudini, H.K.; Bajaj, P.; Fountain, J.C.; Singam, P.; Hong, Y.; et al. Transcriptome analysis identified coordinated control of key pathways regulating cellular physiology and metabolism upon Aspergillus flavus infection resulting in reduced aflatoxin production in groundnut. J. Fungi 2020, 6, 370. [CrossRef] [PubMed]

66. Zhao, Z.C.; Hu, G.B.; Hu, F.C.; Wang, H.C.; Yang, Z.Y.; Lai, B. The UDP glucose: Flavonoid-3-O-glucosyltransferase (UFGT) gene regulates anthocyanin biosynthesis in litchi (Litchi chinesis Sonn.) during fruit coloration. Mol. Biol. Rep. 2012, 39, 6409-6415. [CrossRef] [PubMed]

67. Luo, H.; Laluk, K.; Lai, Z.; Veronese, P.; Song, F.; Mengiste, T. The Arabidopsis botrytis susceptible1 interactor defines a subclass of RING E3 ligases that regulate pathogen and stress responses. Plant Physiol. 2010, 154, 1766-1782. [CrossRef] [PubMed]

68. Caceres, I.; Al Khoury, A.; El Khoury, R.; Lorber, S.; Oswald, I.P.; El Khoury, A.; Atoui, A.; Puel, O.; Bailly, J.-D. Aflatoxin biosynthesis and genetic regulation: A review. Toxins 2020, 12, 150. [CrossRef] [PubMed]

69. Amaike, S.; Keller, N.P. Aspergillus flavus. Annu. Rev. Phytopathol. 2011, 49, 107-133. [CrossRef]

70. Kachroo, A.; Kachroo, P. Fatty acid-derived signals in plant defense. Annu. Rev. Phytopathol. 2009, 47, 153-176. [CrossRef]

71. Pandey, G.K.; Grant, J.J.; Cheong, Y.H.; Kim, B.G.; Li, L.; Luan, S. ABR1, an APETALA2-Domain transcription factor that functions as a repressor of ABA response in Arabidopsis. Plant Physiol. 2005, 139, 1185-1193. [CrossRef]

72. Tsai, A.Y.-L.; Gazzarrini, S. AKIN10 and FUSCA3 interact to control lateral organ development and phase transitions in Arabidopsis. Plant J. 2011, 69, 809-821. [CrossRef]

73. Elahi, N.; Duncan, R.W.; Stasolla, C.; Ehai, N. Decreased seed oil production in FUSCA3 Brassica napus mutant plants. Plant Physiol. Biochem. 2015, 96, 222-230. [CrossRef] 